\title{
Paul Kammerer and the inheritance of acquired characteristics
}

\author{
Jacques J.M. van Alphen ${ }^{1,2,3^{*}}$, Jan W. Arntzen ${ }^{1 *}$ \\ ${ }^{1}$ Naturalis Biodiversity Center, P.O. Box 9517, 2300 RA Leiden, the Netherlands \\ ${ }^{2}$ Institute for Biodiversity and Ecosystem Dynamics, University of Amsterdam, P.O. Box 94248, 1090 GE Amsterdam, \\ the Netherlands \\ ${ }^{3}$ E-mail: jacques.vanalphen@gmail.com
}

* Both authors contributed equally to this work

Key words: amphibia, Arthur Koestler, Darwinism, epigenetics, evolution, Lamarckism

\begin{abstract}
The Austrian biologist Paul Kammerer (1880-1926) would by now be long forgotten if Arthur Koestler had not published 'The case of the Midwife toad', in which he depicted Kammerer as a victim of the paradigm battle between neo-Darwinists and Lamarckists. Kammerer is still on the scientific agenda, with at least 10 publications since 2005. The question is still out if Kammerer fabricated his scientific results or not. In this paper we provide the evidence that Kammerer consistently faked experimental results. We show (1) that the design of his experiments could never have produced the results that he claimed, (2) that the assumptions he made about the developmental biology of the species he studied are falsified by recent research, and (3) that the specimens he showed as proof for the success of his experiments came from nature.
\end{abstract}

\section{Content}

Introduction 457

The Blind cave salamander .

Recent research on reproduction in the Blind cave

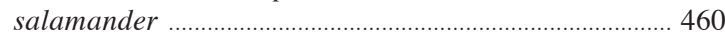

Eye development ..................................................................... 460

Recent research ..................................................................... 461

The Fire salamander .................................................................. 461

Variation in colour patterns ............................................... 462

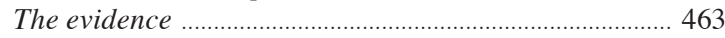

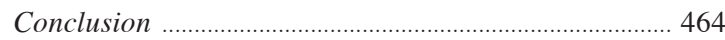

Viviparity in Salamandra salamandra ............................. 464

Kammerer's results ............................................................. 464

Recent research on viviparity in S. salamandra ............. 465

Geographical distribution of viviparity in

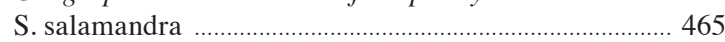

Developmental biology ....................................................... 466

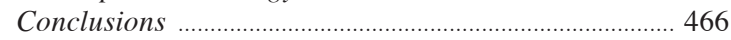

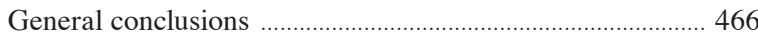

Acknowledgements .................................................................. 468

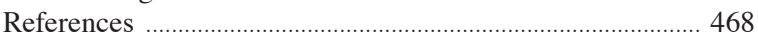

\section{Introduction}

On August 7, 1926 the American herpetologist Noble published in Nature evidence of fraud with scientific results of Paul Kammerer (Noble, 1926). Six weeks later Kammerer committed suicide. Kammerer was a biologist in Vienna, Austria. He studied toads, salamanders and lizards and Noble had discovered that the front legs of his last preserved specimen of the Midwife toad (Alytes obstetricans (Laurenti, 1768)) had been injected with India ink to suggest the presence of nuptial pads. If nuptial pads really had been present, it would possibly have been evidence for an acquired character to become a hereditary trait. Midwife toads mate on land and have no nuptial pads. Kammerer claimed to have bred midwife toads in water over several generations, and that the male descendants now developed nuptial pads in the mating season, like males of water breeding frogs and toads. Kammerer had been unmasked as a scientific fraud. Many saw his suicide as a confession. Probably, Kammerer would by now be long forgotten if Arthur Koestler had not published 'The case of the Midwife toad' (Koestler, 1971). In that book he pictures Kammerer as a victim of the paradigm battle between neo-Darwinists and Lamarckists, and suggests that others had committed the fraud. The book saved Kammerer not only from oblivion, but also placed him back on the scientific agenda: since 2005 at least 10 publications (Gliboff, 2005, 2006, 2010; Coen, 2006; Logan, 2007; Pennisi, 2009; Svardall, 2010; Wagner, 2009; Weisman, 2010; Liu, 2011) have appeared about him and his work, and it has even been suggested that Kammerer is the founder of epigenetics (Sermonti, 2000; Vargas, 2009). Although the events took place in the period 1903-1926, they continue to 
generate discussion and the question is still out if Kammerer fabricated his scientific results or not.

Several aspects in this case impede a clear view of the problem:

1. The language in which Kammerer published. The original publications are in German, a language that not all of the people who have participated in the discussion have mastered equally well, limiting their access to literature.

2. The quality of his publications. In his publications Kammerer is often unclear about the details of the research protocol followed, and - according to current standards - essential quantitative data and statistical analyses are lacking. Where there is clarity about the procedures followed, alternative hypotheses are not excluded and other interpretations of the results are often possible.

3. Phenotypic plasticity. Most of the experimental work of Kammerer involved the breeding of amphibians under ambient conditions (humidity, light, temperature) that differ from those in the natural habitat. Such experiments may reveal phenotypic plasticity. In Kammerer's time, phenotypic plasticity of individual organisms was widely known, but not how it related to genetics. One was not yet aware that the expression of a gene could vary with the environment and thus produce different phenotypes. This also contributed to the confusion about the implications of his experiments. If a different phenotype occurred in a different environment some saw this as an acquired characteristic. It would of course still have to be shown that such an acquired characteristic was also passed on to the next generation to provide evidence for Lamarckian evolution.

4. The role of selection. Another source of confusion is that the experiments did not exclude the occurrence of selection. As a rule Kammerer collected large numbers of animals, which he kept in terrariums. Maybe he already selected particular individuals in the field. In addition, some mortality must have occurred in his terrariums, but he did not provide data on this mortality. Then, animals were exposed to extreme environmental conditions. These must also have caused some mortality. Certainly, high mortality occurred among their offspring, and so it is likely that the specimens that finally survived represented genotypes that were more resistant against the experimental treatment.

5. Paradigm struggle between neo-Darwinism and Lamarckism. At the root of the controversy were fundamental ideological differences: Kammerer believed that inheritance of acquired characteristics played an important role in evolution and his research was aimed to demonstrate just that. Kammerer presented his data as evidence that characteristics acquired by exposure to experimental environments became heritable. Lamarckism was understandably quite attractive to Communists, because of the plastic view of life that was consistent with the plastic view of human nature insisted upon by Marxist-Leninist dogma (Zirkle, 1949, 1959). The Russians even made a film inspired by the life and works of Kammerer (Anonymous, 1961). The film can be seen at YouTube (https://youtube/ 6Au0lh7BuK4) and two stills from the film are here shown as Fig. S1. Kammerer's opponents were neoDarwinians and argued fiercely against Lamarck on the basis of Mendel's and Weismann's theories. They demanded hard evidence from their opponents for the inheritance of acquired characteristics. Weismann discovered that the cells that will be used for reproduction (the germ line) are already set apart during early development (Weismann, 1892). The other cells form the body (the soma). On the basis of this separation Weisman reasoned that new genetic properties acquired by somatic cells cannot be transmitted to the offspring. The controversy also suggested that prejudice rather than scientific arguments played a key role in the debate on Kammerer's claims.

6. No independent replication of Kammerer's experiments. A scientific solution of the disagreement could have been that Kammerer's opponents would have repeated his experiments, but Kammerer worked with amphibians with long generation times, some of which are difficult to breed in captivity. Repeating the experiments would have been an even greater challenge, as this requires breeding under conditions normally not experienced by the animals. For example, to breed midwife toads in the water is an impossible task. A carrying male will routinely shed the egg string at slight disturbance. Many have tried to raise the embryos from such an abandoned clutch, with no success. Kammerer's work on the Sea squirt Ciona intestinalis (Linnaeus, 1767) has been repeated, but the results could not be duplicated (Fox, 1923, 1924; Whittaker, 1975, 1985).

7. No preserved specimens available. Another problem is that no material has been preserved that researchers could use now to verify some of Kammerer's claims using present-day, molecular genetic techniques. 
With current scientific knowledge, we can unambiguously state that Kammerer's research has provided no evidence for the heritability of acquired characteristics. Its relevance is thus limited to that of a dramatic illustration of the history of biology in the early 20th century. Nevertheless, 'The case of the Midwife toad' has rehabilitated him, in particular in the eyes of historians of science, as an original researcher who was the victim of a paradigm struggle and fraud committed by others. It is therefore of interest to know whether Kammerer was an impostor or not. In the following, we will show that there cannot remain any reasonable doubt that Paul Kammerer faked his experimental results. We will discuss his research on the Blind cave salamander (also known as Olm, Proteus anguinus

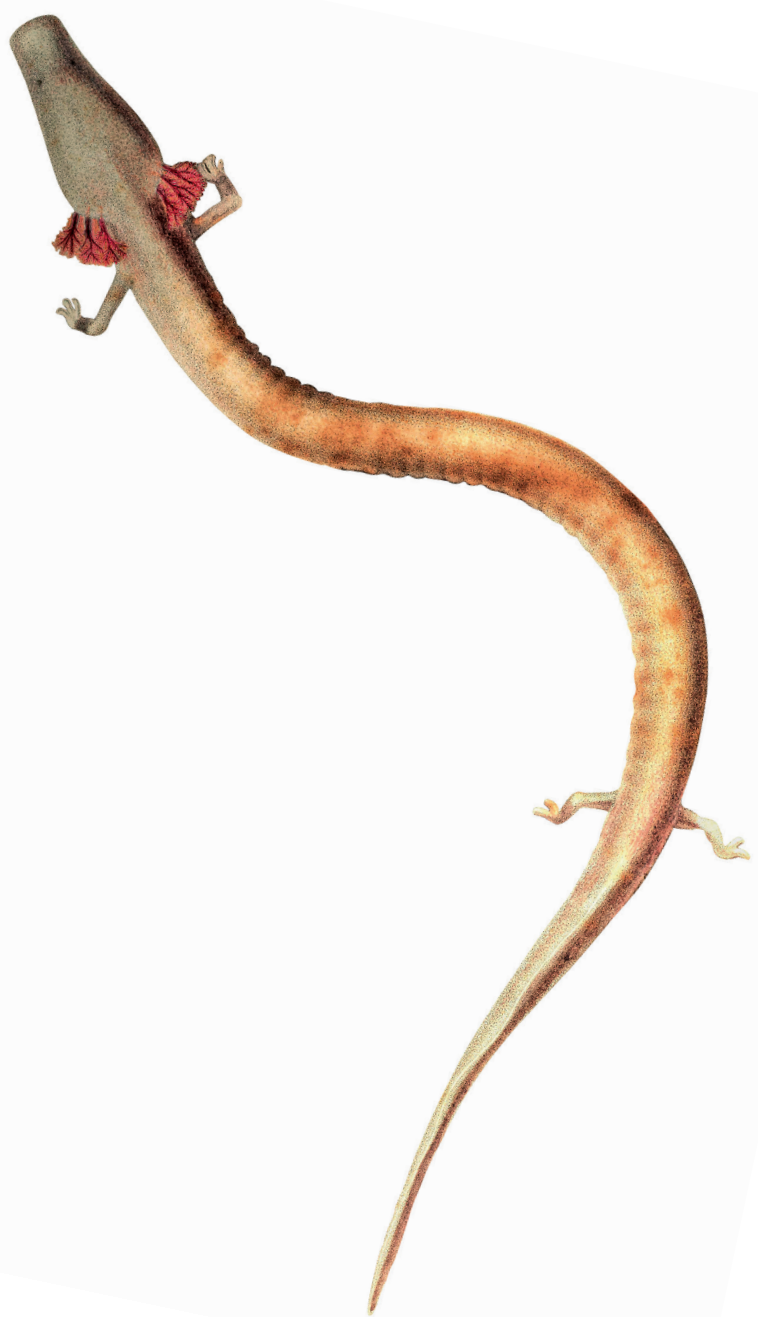

Fig. 1. The Blind cave salamander, Proteus anguinus (from Configliachi and Rusconi, 1819).
Laurenti, 1768) and the Fire salamander (Salamandra salamandra (Linnaeus, 1758), as we can better judge that work, because of new scientific information that has become available. We will also briefly comment on his research with the Midwife toad and the Sea squirt. For an overview of the academic career of Paul Kammerer and some of his experimental work see Hirschmüller (1991) and Senglaub (2006).

\section{The Blind cave salamander}

The Blind cave salamander (Proteus anguinus) occurs in the Dinaric Karst, where it is found in underground rivers. The animals have little or no pigment and no functional eyes (Fig. 1). For Kammerer, the Blind cave salamander was an attractive species to work with. It was still a mystery how and where cave salamanders reproduced in nature and only a few people had managed to breed them in captivity (Honigmann, 1908 and references therein). The popular belief was that they were viviparous, but there was, except for anecdotes, no evidence, and it was contradicted by several early observers who observed egg-laying by a captive animal (Schulze, 1876; Chauvin, 1883; Zeller, 1889).

Nobody could therefore assess whether the results claimed by Kammerer were reliable. He claimed that his Blind cave salamanders reproduced in the laboratory, and that they were viviparous (Kammerer, 1907a, 1912), a claim also made by Nusbaum (1907) and later by Joseph (1933) who worked with animals from the same stock as that of Kammerer and in the same laboratory. They would deliver two juveniles, as the Alpine salamander (Salamandra atra Laurenti, 1768) (Schwalbe, 1896; Greven, 2003). Kammerer also claimed that his cave salamanders had laid eggs several times, but that this was due to the unnatural conditions in the laboratory, particularly because they were exposed to daylight and higher water temperatures. Thus, he described how a pair kept in daylight in a given year laid eggs, but that the same pair when transferred to a dark basement produced two young the following year. Of another female, he described that it produced larval offspring on three occasions over a four year period (at 18-19 October 1907, on October 30, 1908 and on 10 November 1910) and once laid eggs on a later occasion. Kammerer obviously assumed that cave salamanders reproduce every year, or nearly so. The new-born young cave salamanders had a length of 10 to $12 \mathrm{~cm}$, which is the length of the smallest cave salamanders that were available commercially. Kammerer described his results in 
great detail, giving them a reliable flavour. Let us now compare his data with those of recent research.

\section{Recent research on reproduction in the Blind cave salamander}

Since 1948, an introduced population of cave salamanders has been held for scientific research in caves in Moulis and Aulignac, France. Voituron et al. (2011) describe the exceptional life history of the cave salamander based on data collected over 52 years. Females become mature at an age of about 15 years. They then lay an average of 35 eggs and reproduce on average once every 12.5 years. This number conforms to data by Briegleb (1962) on the advanced age at maturity. Juberthie et al. (1996) report reproduction events on average every six years for the same captive population, a value confirmed by Gregor Aljančič for a different captive population originating from the same source (GA pers. comm. December 2015), but even this is an extremely slow rate of reproduction. The slow growth and reproductive rates are compensated for by an exceptionally long lifespan: based on known facts the maximum lifespan of the cave salamander is estimated to be more than a hundred years. The cave salamanders in Moulis are kept under semi-natural conditions and lay eggs, while Kammerer claimed that egg-laying occurred only when they were kept at a higher temperature than the natural and that under natural conditions, they produced two young. The cave salamanders in Moulis reproduce with breaks of 4.5-7 years, those of Kammerer every year or every second year. Such a dramatic difference in life history within the same species can only be expected between populations evolved under very different ecological conditions.

\section{Eye development}

Kammerer found that when cave salamanders were held in daylight they developed pigment, and that this happens especially in young animals, which became pitch black. Other authors have also observed the pigment formation in cave salamanders that are kept in light. Furthermore, Kammerer claimed that animals kept from childhood alternately in daylight and red light also developed larger eyes. These remained covered by the skin, but by removing the skin surgically,
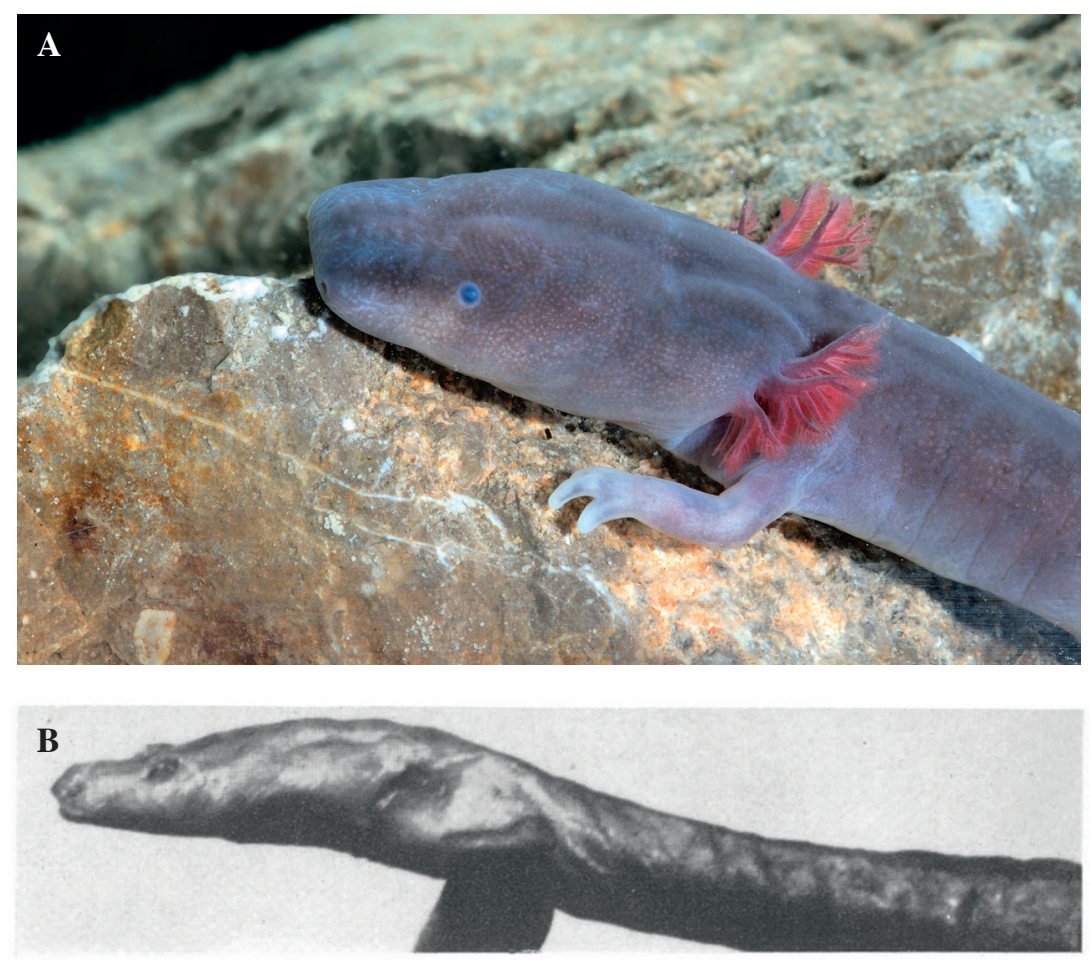

Kammerer's specimen of Proteus with eyes restored, exhibited in Cambridge and London, 1923. Photo: B. Stewart, Cambridge.
Fig. 2. Black cave salamander Proteus anguinus parkelj (A) compared with Kammerer's Proteus with eyes (B, reproduced from Koestler, 1960). Note the short snout relative to the nominotypical subspecies in Fig. 1. For a comparative analysis at the level of the skull see Ivanović et al. (2013). A - Photo courtesy and copyright Vilda/Rollin Verlinde. 
he claimed to have created a cave salamander with functioning eyes. This animal was preserved and when Kammerer visited Cambridge in 1923 he took the specimen with him. Professor MacBride of Imperial College, at that time holder of the Chair of Zoology, said about that "Whatever hesitation may remain about accepting Kammerer's results in other matters, there can be no dubiety about his results on Proteus" (MacBride, 1925). In England this cave salamander was photographed and the picture is printed in Koestler's book (Fig. 2). The photo shows the front part of a dark cave salamander, with eyes clearly visible. In Kammerer's (1912) publication there are also photos of this specimen.

\section{Recent research}

It does look quite convincing, but is there really no doubt? Again, we compare with recent research. Durand (1976), using individuals from the Moulis population, studied the development of the eyes of the Blind cave salamander. He repeated Kammerer's experiments to determine whether the presence of light actually leads to the regeneration of the eyes: "Young specimens of Proteus were exposed to the action of daylight for 6.5 years. Others were exposed to artificial light of wave-lengths between 600 and $1200 \mathrm{~nm}$ (i.e., within the red and infrared range of the spectrum). This continued for the first 10 years of age. After several years, individuals exposed to light become bluish-black. Over the same time, even if the eye is initially relatively well developed, the corneal ectoderm thickens, the lens diminishes in size and eventually disappears." He also describes reciprocal transplantation experiments of the eyes with those of the Pyrenean brook salamander (Calotriton asper (Dugès, 1852)) and concludes that all anatomical and experimental data show that the development of the eye and the disappearance of the lens in the Blind cave salamander is controlled by hereditary factors, and is hardly affected by the environment. So the question is, how did Kammerer come in the possession of a cave salamander with functional eyes? He is not very clear about the origin of the cave salamanders that he used for his research. Many of the ones that he used in the daylight experiments came from Postojna in Slovenia, but he claims that the animal that he operated was born in his laboratory, and he provides no information on the origin of the parents. Kammerer writes elsewhere that he had bought cave salamanders originating from a variety of localities. Interestingly, Bulog et al. (2000) report variation between different populations in eye degeneration: "Recently, we have begun to study the photoreceptors in the rudimentary eye in different populations of Proteus. The ultrastructural analysis is providing interesting results about the different levels of structural degeneration of photoreceptor cells in different populations."

In 1986 a black subspecies of the cave salamander was discovered in South East Slovenia, with normal functional eyes (Aljančič et al., 1986; Sket and Arntzen, 1994). Was Kammerer in the possession of a cave salamander of this subspecies, which at the time was unknown to his scientific contemporaries? The shortsnouted head of the animal is typical for the new subspecies P. a.parkelj Sket and Arntzen, 1994 (Fig. 2). In any case, Durand has demonstrated convincingly that exposure to daylight or red light does not result in the development of functional eyes.

One would expect that Kammerer would have grown the cave salamanders that were adapted to dayor red light during one or more extra generations, to determine if the changes had become hereditary. We now know that under natural conditions, that juvenile cave salamanders live hidden and hardly move and that it takes 12 years or more before it reproduces for the first time. The protocol thus would have lasted a very long time. Kammerer does not use this argument, but instead says that he will not continue his work with cave salamanders into the next generation, because the critics would not accept the results anyway. In retrospect, it seems that there is no evidence that he ever obtained a laboratory born generation. His data on the mode and frequency of reproduction of the cave salamander are fictional and are almost certainly based on what he knew of the Alpine salamander, combined with the absence of observations on juvenile cave salamanders in nature.

\section{The Fire salamander}

The Fire salamander (Salamandra salamandra) is a forest dweller with a wide distribution across Europe. They are black with yellow spots or stripes, according to the subspecies. Eastern European fire salamanders are predominantly black with scattered yellow spots. The Western European ones have two, often interrupted yellow bands on the back and head. The differences in colour pattern between populations are heritable (Thiesmeier and Grossenbacher, 2004). The widest variation is found in the Iberian Peninsula (Fig. 3). 


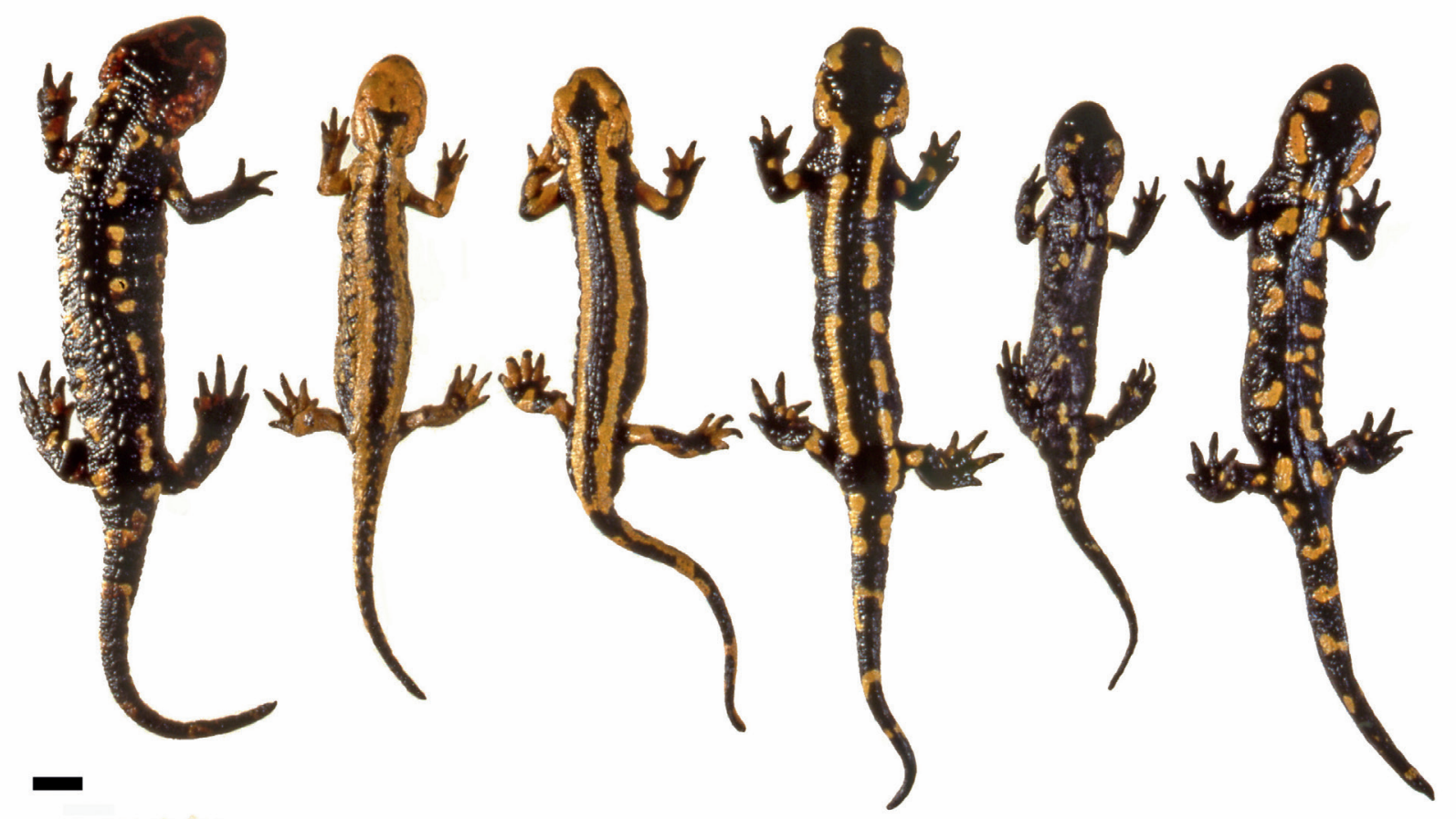

Fig. 3. Morphological variation of Salamandra salamandra subspecies in the Iberian Peninsula, geographically arranged from West to East S. s. gallaica, S. s. bernardezi, S. s. fastuosa and S. s. terrestris Lacépède, 1788 in Northern Spain, followed by two subspecies from Central Spain S. s. almanzoris Müller and Hellmich, 1935 and S. s. bejarae Wolterstorff, 1934. The bar in the lower left hand corner represents one $\mathrm{cm}$. Photo courtesy M. Alcobendas.

Those in the Pyrenees and northern Spain have broad yellow bands on the body. Schreiber (1912) described this most dramatically coloured subspecies (Salamandra s. fastuosa Schreiber, 1912). In 1913 Schreiber's collection was purchased by the Vienna Museum and catalogued by Otto Wettstein, who also dealt with the taxonomic treatment of the lizards collected by Kammerer in the Adriatic region (Kammerer and Wettstein, 1926; Adler, 2007).

\section{Variation in colour patterns}

The colour pattern of fire salamanders functions as a warning colour (aposematic coloration). The salamanders can only walk slowly and thus cannot easily escape predators, but they are in the possession of venom glands. The combination of warning colours and venom glands helps them to scare off predators (see Brodie and Smatresk, 1990). The salamanders are primarily nocturnal. They mate on land. The eggs develop in the body of the female, which drops the larvae in streams or ponds, or gives birth to a small number of metamorphosed young, as it happens in some Iberian populations (subspecies S. s. fastuosa and S. s. bernardezi Wolterstorff, 1928). As long as the larvae live in water, they are cryptically coloured, but once they go on land they change to the black body colour with yellow spots. Kammerer housed young salamanders on a yellow or black background. He expected that the animals would adapt their colour pattern to that of the environment in the course of time. He had this idea already when he published his PhD.-research (Kammerer, 1904). He was well acquainted with the geographical variation of fire salamanders, because he obtained material for his studies from many places in Europe, including the French Pyrenees (Kammerer, 1904). He was also aware of the work of Bedriaga (1897) and Schreiber (1875) figuring the heavily striped forms. Kammerer believed that the amount of black and yellow partly related with the local climate and, consequently, that fire salamanders in cold areas were less yellow than those in warmer areas. He also believed that there was an effect of the soil type on which the salamanders lived, for example, that those on lime and loam soil were more yellow. Although he was familiar with the idea that the yellow-black colour 
combination of fire salamanders could be a warning signal, he thought that it simultaneously functioned as cryptic coloration. His argument is as follows (Kammerer, 1904 p. 232): “ ... how hard it often is, and what a trained eye is needed, to recognize a fire salamander between the fallen yellow autumn leaves and the yellow mushrooms that grow from the black forest floor, or not to confuse the animal with a curved piece of branch of which the bark is peeled off in part and shows wet and shiny yellow spots." He explained the differences in colour pattern between populations as a result of individual adjustment to the colour of the soil on which they lived. He ignored other possible explanations, e.g. that genetic differences between subspecies are at the basis of the differences in colour pattern, and that natural selection by predators and / or the thermal environment have played a role in the evolution of those differences. Therefore, no good reason existed to expect that fire salamanders would adapt their colour pattern to the colour of the environment in experiments.

Yet, he claimed that his experiments had provided the evidence that salamanders adapted to the colour of their background (Kammerer, 1911 p. 279-280): "If we keep the fire salamander (Salamandra maculosa) years on yellow loam soil, then his yellow markings increase at the expense of the black background. If we breed half of the offspring of such animals that have become very yellow, again on yellow earth, then the amount of yellow increases again and wide bilaterally symmetrical longitudinal bands appear [...], if the other half of the progeny is grown on black earth they become less yellow, with still a lot of yellow in relation to the environment that works in the other direction, and also in two regular rows of spots on both sides of the body."

\section{The evidence}

As evidence, Kammerer published some photographs and a large number of drawings of the colour patterns of salamanders. The photos were hand-coloured and some of them retouched. Kammerer said that he retouched the photos, because some spots had become invisible by the reflection of light on the shiny skin of the salamanders, or spots were suggested that were not there. This did not improve the value of the photos as scientific evidence. Likewise, the drawings can hardly be considered as evidence for his results. As an example we use the plates in Kammerer (1910) representing salamanders kept on black or yellow paper (Plates III and IV). They show individuals at the beginning of the treatment and, as he writes in the accompanying figure caption: "the same specimen after 4 years". They would constitute the evidence that salamanders kept on yellow paper become more yellow, and those kept on black paper blacker.

Baur (1914) objected to the retouching of the photos and pointed out that not only the spot size, but also the colour patterns had become different after four years, and therefore could not involve "the same specimen". If you examine the plates in Kammerer's article in detail, you see indeed many small inconsistencies. For example, a salamander held on black soil has not only smaller spots after four years, but also new yellow spots in places where they first were not, while the spots of an animal kept on yellow earth have not only become larger but have also changed position.

Kammerer admits in his reaction "That they are not the same animals is evident from their different colour patterns" but he downplays that fact and apologizes for using the words "the same specimen": "I admit that the text used in the caption can be misunderstood, and thank Prof. Baur for providing me the opportunity to confirm that explicitly." (Kammerer, 1914 p. 684). But there is really no question of misunderstanding, the same specimen is not a different specimen! It cannot be denied that Kammerer was dishonest in that quote, he wrote that Eastern European fire salamanders with an irregular pattern of small yellow spots change when kept on a yellow background, and will then resemble the banded West European subspecies. This ignores the problem that the colour pattern of individuals then has to change considerably, while he apparently was aware of the fact that the colour patterns of individuals are quite stable and can be used to recognize individuals. Curt Herbst (1924), who repeated Kammerer's experiments concludes: "in contrast to the results by Kammerer (1913), neither extremely yellow animals could be grown in a in yellow background, nor very dark animals in black surroundings." He found only subtle changes in colour with age. Recent research confirms this. Wisniewski and Wisniewski (1998) found that $S$. s. salamandra colour patterns changed relatively little over a period of twelve years. Pederzoli et al. (2003) investigated the formation of colour patterns during the development of fire salamanders and write: "In S. salamandra in particular, the definitive pattern of chromatophores develops at metamorphosis, through a deep structural remodelling of the integument, and only slight changes may occur subsequently." Some evidence for a change of colour pattern 
with age comes from a fire salamander on Corsica (Beukema, 2011). Photos of 35 animals show that larger individuals had more, and more irregularly shaped spots. Even if we would accept a comparison of different individuals as evidence for ontogenetic change in colour pattern with age, there is still no evidence that this happens in response to background colour. Likewise, Balagova and Uhrin (2015) showed that spot size increased with size in S. salamandra from Slovenia, but not in response to background colour.

\section{Conclusion}

The inescapable conclusion is that Kammerer used salamanders from different sources to suggest that individuals changed colour when placed on yellow or black backgrounds. Bateson and Boulanger had suspected that already back in 1910 . They compared the fire salamanders in the collection of the British Museum from different sites in Europe. They found no transitions between the striped subspecies of Western Europe and the irregularly spotted one from Eastern Europe (Bateson, 1913), which one would expect if fire salamanders would adapt phenotypically in colour pattern to the background colour of the environment.

\section{Viviparity in Salamandra salamandra}

In his thesis research Kammerer compared the reproduction of the Alpine salamander, S. atra, with that of the Fire salamander, $S$. maculosa (= S. salamandra) (Kammerer, 1904). Fire salamander females most often are ovoviviparous, and produce 30-60 larvae at some stage before metamorphosis is complete (Schwalbe, 1896), with the yolk allocated to the egg being their only source of nutrition (also called larviparity; Greven, 2003). Alpine salamander females are viviparous and, as a rule, produce only two metamorphosed offspring ('pueriparitry'). The larvae and metamorphs feed on the yolk provided by the mother, but in addition on infertile eggs and the yolk mass resulting from their disintegration.

\section{Kammerer's results}

Kammerer reasoned that viviparity is an adaptation to the harsh conditions and the lack of suitable aquatic habitats at high altitude. He argued that it should be possible to create viviparous $S$. salamandra females by denying gravid females access to water. Without providing much detailed results he concludes: (Kam- merer, 1904 p. 254) "Females of Salamandra maculosa that have been denied the possibility to deposit their offspring in water, keep their young in the uterus until metamorphosis has been completed (habitual late births), which is accompanied by a reduction in the clutch size." He underpinned this conclusion with detailed evidence (p. 227): "However, provided that the humidity of the terrarium is too low for the development of such animals, born with external gills, then, two to three years, i.e., four to six pregnancies, are needed before the adaptation is completed and the offspring are born with either tiny functionless rests of the gills, or without gills, but the gill slits still open, or, finally, with closed gill slits as fully metamorphosed salamanders." He continued to state (p. 227): "The viable larvae are born at an increasingly larger size and closer to metamorphosis, but are also produced in smaller numbers, while the rest of the clutch is retarded in its development and almost always crippled." In the conclusions at the end of the paper (p. 254) this becomes: "The intra-uterine conditions of such female S. maculosa that give birth late, resemble those of Salamandra atra: as only a reduced number of eggs develop into embryos, the large proportion of the eggs that do not develop turn into a mass of yolk that serves as food for the developing embryos" (Note the difference with the previous statement). He also reported differences between populations and stated that some populations make the shift to viviparity more easily than others (p. 230) "I will not refrain from pointing out that the whole progress in the adaptation of those females coming from localities at high altitudes [...] is faster and easier (with lower mortality after the first clutch has been born on land in comparison with those from the plains and the hills [...]." These citations show that Kammerer believed that fire salamanders are plastic in their reproductive mode, and that when they have to give birth in the absence of water individuals will become viviparous after some time, and progressively more so with each new reproductive cycle. Kammerer assumed that the development of larvae that were retained longer in the uterus, because the mother had no access to water to give birth, progressed along the same timeline as those that had been born and deposited into the water i.e. that viviparity does not involve heterochrony.

In a next publication (Kammerer, 1907b) he summarized the results of the 1904 paper. He repeated the statement that aborted eggs form a yolk mass that serve as food for the foetuses "Eggs that fail to develop, the so-called aborted eggs, which, like the yolk 
mass in the uterus of Salamandra atra, are occasionally eaten by the foetuses" (p. 9). However, it is hard to see how this would be possible in ovoviviparous salamanders, as the foetuses stay within the egg membranes until birth. Kammerer recognized this problem and excluded animals from lower altitudes from this behaviour (p. 9-10): "On the other hand, the embryos of Salamandra maculosa at low altitude are until the moment they are born still within the egg membranes, which burst during the next few minutes." He suggested that there are (genetic) differences between populations at higher and lower altitude (p. 9): "Several times I have found fire salamanders at higher altitudes, which contained a relative small number of far-developed larvae, which had been gorging themselves on the merging eggs that were their kin".

Kammerer concluded that populations from higher altitudes are not ovoviviparous, but viviparous and says that these salamanders give birth to a similar number of aquatic larvae as the ovoviviparous ones from lower altitude (p. 45) "In nature and under normal conditions in captivity, Salamandra maculosa is viviparous and then gives birth in water to a variable but always considerable number (up to 72), 25 to 30 mm long, four-legged and short-gilled larvae [..] mountain regions and higher hills - or is ovoviviparous and then also gives birth in water to a similar large number of eggs of 11 to $13 \mathrm{~mm}$ diameter, from which immediately or a few minutes after being laid the 23 to $25 \mathrm{~mm}$ long larvae emerge [...] - lower hills and lowland plains". Nevertheless, he maintained that lowland fire salamanders as described in his first paper, can change their reproductive mode from normal ovoviviparity to viviparity and give birth to fully developed offspring on land. They then become similar to females from higher altitudes (p. 10)"But because of the retention of a smaller than the usual number of larvae in the uterus, the other embryos must atrophy and perish. In Salamandra maculosa females that have become habitual in giving birth late, a fraction of the eggs dissolves from the beginning to form a yolk mass and serves the small number of growing foetuses as food". To make this possible the embryos would have to emerge from the egg membranes a long time before they are born and they would need a well-developed mouth and digestive track. That means that, in addition to the longer retention of larvae by the mother, a heterochronous shift in the development of the larvae is needed. This earlier development would have to occur before the females were denied access to water, in other words the female (and the embryos) would have to anticipate the treatment imposed on them later.

A similar problem in understanding Kammerer's results is that it is difficult to think of a mechanism that would cause the females to change their reproductive mode progressively with each pregnancy. This is particularly so because the animals were housed in terrariums with water basins throughout a large part of the year, to encourage them to mate and enter a new reproductive cycle. They were denied access to water only when they were pregnant and close to giving birth. It is hard to believe that such a protocol can result in a progressive change to viviparity. His results also raise the questions why the phenotypic plasticity in reproduction mode reported by Kammerer (1904: Table A on p. 245) has never been observed in nature in the populations that he used for his experiments, and why as yet others have not confirmed the existence of viviparous $S$. salamandra at higher altitudes in central Europe (Thiesmeier and Grossenbacher, 2004).

\section{Recent research on viviparity in $\mathrm{S}$. salamandra}

Since Kammerer's days we have learnt a lot on viviparity in S. salamandra. Indeed, diversity in reproductive strategies exists in the Fire salamander. Female $S$. salamandra may be ovoviviparous, in which case 30-60 larvae are produced at some stage before metamorphosis is complete, with the yolk allocated to the egg being their only source of nutrition. Alternately, female fire salamanders can be viviparous. In this phylogenetically derived reproductive mode (Dopazo and Alberch, 1994; Veith et al., 1998; García-París et al., 2003), one to 15 fully metamorphosed juveniles are born.

Geographical distribution of viviparity in S. salamandra

Viviparity occurs in populations belonging to the subspecies S. s. bernardezi in the Cantabrian Mountains, in the SW Pyrenees (S. s. fastuosa) and on two Spanish islands with S. s. gallaica Seoane, 1884 (Velo-Antón et al., 2007, 2012). Molecular phylogenetic studies show that viviparity is a derived trait and support the hypothesis that viviparity in mainland Iberian populations of $S$. salamandra evolved only once during the Pleisotocene (Alcobendas et al., 1996; García-París et al., 2003). Viviparity on the Spanish islands has evolved independently more recently and perhaps more rapidly (ca. 9000 yrs, Velo-Antón et al., 2012). Throughout the remainder of its distribution area, the reproductive mode is ovoviviparity; viviparity is not 
known in populations from which Kammerer's experimental animals originated (Austria, Germany, Slovenia, Switzerland), except perhaps two animals (S. $s$. fastuosa) from Bagnères de Luchon in the French Pyrenees (Kammerer, 1904). The geographic distribution of viviparity and its phylogenetic history (García-París et al., 2003; Velo-Antón et al., 2012, 2015) are evidence for a genetic basis of viviparity and argue against the hypothesis of plasticity of reproductive modes in $S$. salamandra.

\section{Developmental biology}

Viviparity in S. salamandra is characterized by a number of adaptations, expressed in the mother or in the embryo (Buckley et al., 2007):

1. Viviparous females, like ovoviparous ones, ovulate numerous eggs, but they develop through metamorphosis entirely within the maternal genital tract and few (1-15) fully metamorphosed terrestrial juveniles are born after 80-90 days of gestation.

2. In viviparous females development is arrested in many eggs.

3. The embryos are disposed differently on the yolk masses; cephalic and caudal regions are clearly elevated in the ovoviviparous embryos, the viviparous ones are tightly curled around the yolk.

4. Viviparous embryos hatch precociously after 8 or 9 days of development, oviviparous ones after 80-90 days.

5. The cephalic and pharyngeal regions of the viviparous embryos are enlarged and advanced in development relative to those of ovoviviparous embryos.

6. Developmental rates of the viviparous embryos are heterogeneous, whereas ovoviviparous embryos develop in synchrony.

7. The mouths of the viviparous embryos open and the balancers are resorbed earlier in viviparous than in ovoviviparous embryos.

8. The yolk mass of the viviparous embryos is drastically reduced and the anterior part of the digestive tract is developed. Viviparous embryos attain this stage after 12 or 13 days, whereas the ovoviviparous embryos require approximately 19 days.

9. Viviparous embryos start to feed actively within the maternal oviducts. Feeding includes predation on arrested eggs and other embryos. In summary, the developmental program of viviparous fire salamanders is accelerated in comparison with that of ovoviviparous ones. Hatching occurs much earlier and the structures involved in feeding, mouth and diges- tive tract, develop sooner in comparison with those in ovoviviparous fire salamanders. This permits the precocious feeding by viviparous embryos. Hence, viviparity in the Fire salamander is accompanied by heterochronous development and involves a complex suite of adaptations, of which many are expressed in the embryo, as in vitro experiments on egg and embryo development show (Buckley et al., 2007; Wake, 2015).

\section{Conclusions}

It is highly unlikely that Kammerer (1904) succeeded in changing the reproductive mode of individual fire salamanders ( $S$. salamandra) from ovoviviparity to viviparity. All available evidence shows that viviparity in the Fire salamander is under genetic control and not a phenotypically plastic character that can be brought to expression by denying gravid females of ovoviviparous populations access to water. The evolution of viviparity in the Fire salamander requires a number of mutations, most of which are expressed in the offspring, and not in the mother. There is no plausible mechanism in Kammerer's experiment that could have resulted in the progressive shift to viviparity of females that were repeatedly forced to give birth on land.

Kammerer reported differences in reproductive mode between lowland populations and populations from higher altitudes, although he provided different and contradictory versions of the details. Such differences are unknown from central Europe, where the majority of the experimental animals used in Kammerer's experiments came from. Viviparous populations are only known from Spain. Kammerer was aware of the striped forms (bernardezi / fastuosa) from the south of France and northern Spain (Kammerer, 1904 p. 232). These forms are viviparous.

\section{General conclusions}

If we take Kammerer at his word, he always found what he sought, not only in his research on midwife toads, cave salamanders and fire salamanders, but also in his work on lizards and the Sea squirt Ciona intestinalis. There is a common pattern in all these studies. Kammerer knew what he sought, because he was aware that it already existed in nature: variation in colour pattern in the Fire salamander, viviparous fire salamanders, male midwife toads with nuptial pads, cave 


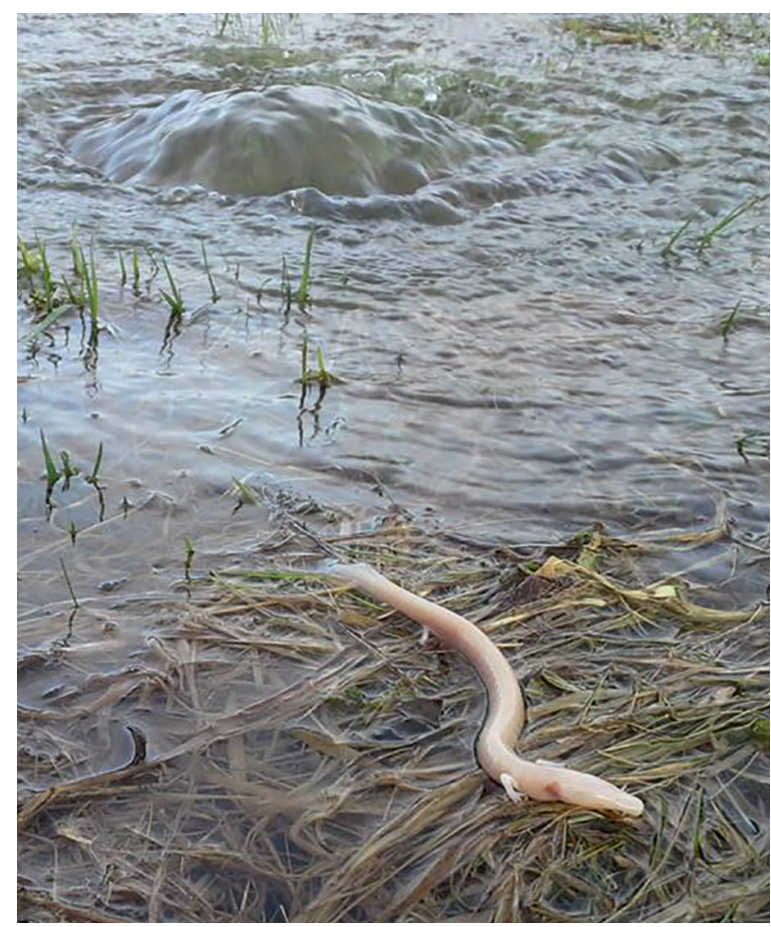

Fig. 4. Blow hole with a ca. $18 \mathrm{~cm}$ long subadult Proteus anguinus washed out. Photo courtesy and copyright T. Hribar.

salamanders with functional eyes, melanistic lizards and long-tubed Ciona are all known to occur in nature. Some if not most of this natural variation was unknown to his colleagues at the time. It is at astonishing that Kammerer was aware of cave salamanders with well-developed eyes such as P. a. parkelj. However, this taxon was known to local people long before it was discovered for science (G. Aljančič, pers. comm.). Every now and then Proteus individuals are washed out of a blow hole (Valvasor, 1689; Aljančič et al., 2016, see Fig. 4) and he may have stumbled upon the find on a trip to Postonja cave (Kammerer, 1905), or bought it on the market in Triest (Shaw, 1999) on his way from Vienna to the Dalmatian coast (Kammerer, 1917). Kammerer was undoubtedly a good natural historian and an excellent observer. He was the first to know about a taxon of cave salamanders with welldeveloped eyes and the first to discover viviparity and intra-uterine cannibalism in fire salamanders. Instead of publishing these new facts on natural variation, he decided on trying to recreate them in the laboratory as acquired characteristics.

We have shown that the experimental design of Kammerer's fire salamander experiments could not have produced the changes he claims. This is also true for his experiments on nuptial pads in midwife toads. Kammerer forced pairs of midwife toads to breed in water, assuming that males without nuptial pads would have problems to hold the females (and therefore develop nuptial pads). He overlooked the fact that malemale competition is the main reason why it is important for an amplexing male frog or toad to hold the female and thus to have nuptial pads (e.g. Fig. 5). Moreover, in midwife toads intra-sexual competition is frequently between females for access to males (Verrell and Brown, 1993). Likewise, it is hard to see why growing larger siphons by Ciona would occur in response to the experimental amputation.

As early as 1904, Kammerer outlined his research program: it aims to show that i) animals acquire new characters when exposed to a different environment, and ii) these changes are inherited by the next generations. He actively promoted the idea that animals can adapt to new circumstances and that these changes are hereditary. "So precisely does protoplasm comply with our wishes that it is soft wax in our hands." (Kammerer, 1920, cited in Gliboff, 2005).

Kammerer knew what he wanted to get, but his Lamarckian research program could not bring him there, because what he had observed was the product of genetic differences and natural selection. When the animal experiments did not comply with his wishes, the only solution was to fabricate the results of his experiments. To support his claims, he employed specimens that he had acquired elsewhere, namely a rare specimen of Midwife toad with nuptial pads (Kändler, 1924), the Blind cave salamander with eyes and the various colour forms of the Fire salamander with different reproductive modes. This single modus operandi also applies to Ciona of which short- and longsiphoned forms of the sort depicted by Kammerer as the results of his experiments are found in different parts of the Mediterranean (Whittaker, 1975, 1985). To this we add Kammerer's own words 'Nature ... has anticipated most of the experiments of the research worker' (Kammerer, 1924 p. 60).

Gliboff (2006) agrees that all the results reported by Kammerer fall within the naturally occurring variation and concludes that "There is no need to invoke fakery to defend neo-Darwinism". We agree, but wish to stress that fakery was required to defend Lamarckism. We have shown that Kammerer cannot possibly have obtained the results that he claimed to have, and hence we conclude that he fabricated the data. He already faked data for his PhD.-thesis and continued to do so during 


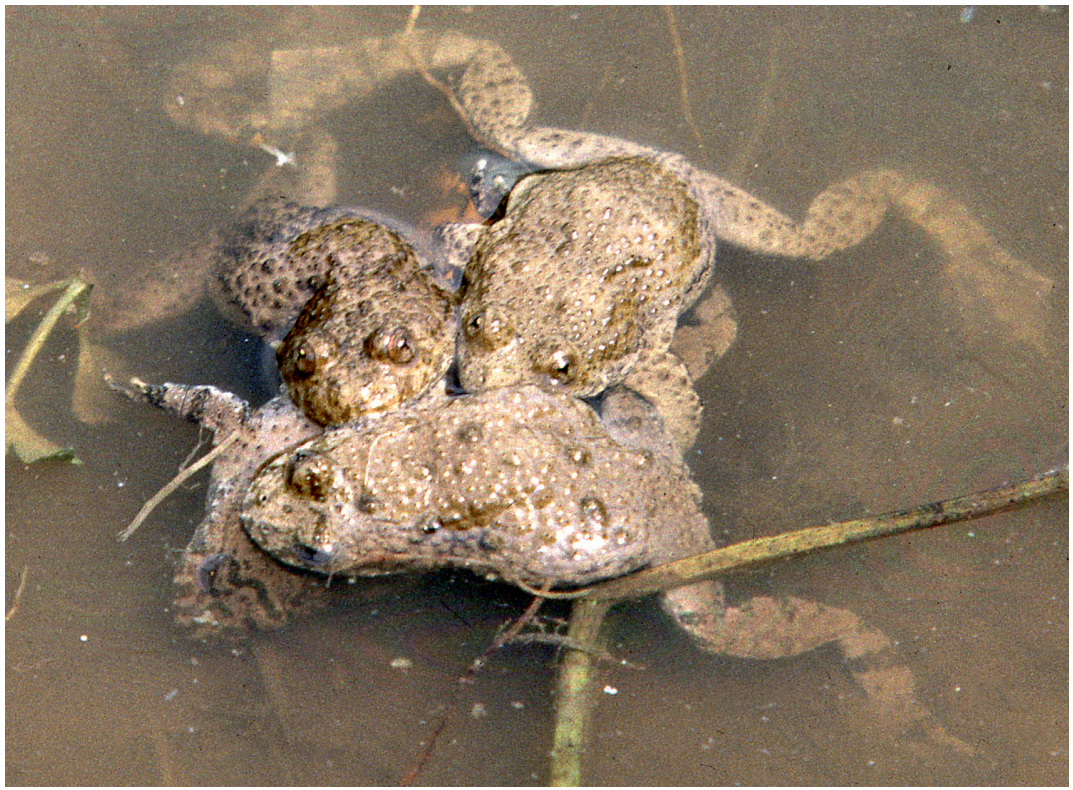

Fig. 5. A 'mating ball' of the Yellow bellied toad (Bombina variegata (Linnaeus, 1758)). Three males are competing for access to the female (left, under water). Nuptial pads and muscular arms help the amplexing male in the front to hold-on, indicating that these characters are under strong intra-sexual selection. Photo J.W. Arntzen.

the years he worked at the Biologische Versuchsanstalt. We thus strongly disagree with Gliboff (2005) that "his evidence was probably genuine".

\section{Acknowledgements}

We thank S. Verhulst for discussion and comments on a previous draft of the manuscript, G. Aljančič for literature, translation from Slovenian, and support and S. Kuzmin and B. Timofeev for assistance. JWA acknowledges financial support by the Welcome Trust.

\section{References}

Adler K. 2007. Contributions to the History of Herpetology. Volume 2. Society for the Study of Amphibians and Reptiles, St. Louis.

Alcobendas M, Dopazo H, Alberch P. 1996. Geographic variation in allozymes of populations of Salamandra salamandra (Amphibia: Urodela) exhibiting distinct reproductive models. Journal Evolutionary Biology 9: 83-102.

Aljančič M, Habic P, Mihevic A. 1986. Black olm from White Carniola. Nase Jame 28: 39-44. [in Slovenian]

Aljančič G, Aljančič M, Golob, Z. 2016. Salvaging the washedout Proteus. Natura Sloveniae 18: 65-67.

Anonymous [various authors] 1961. Annotated Catalogue of Soviet Artfilms. Volume I. Mute Films 1918-1935. Iskusstvo Publishers, Moscou. [in Russian]

Balogova M, Uhrin M. 2015. Sex biased dorsal spotted patterns in the fire salamander (Salamandra salamandra). Salamandra 51: 12-18.
Bateson W. 1913. Problems of Genetics. Yale University Press, New Haven, London.

Baur E. 1914. Bemerkungen zu Kammerers Abhandlung: Vererbung erzwungener Farbänderungen. IV. Archiv für Entwicklungsmechanik der Organismen 38: 682-684.

Bedriaga J von. 1897. Die Lurchfauna Europas. II. Urodela, Schwanzlurche. Moscou.

Beukema W. 2011. Ontogenetic pattern change in amphibians: the case of Salamandra corsica. Acta Herpetologica 6: 169174.

Briegleb W. 1962. Zur Biologie und Ökologie des Grottenolms (Proteus anguinus Laur. 1768). Zeitschrift Morphologie Ökologie Tiere 51: 271-334.

Brodie ED, Smatresk NJ. 1990. The antipredator arsenal of fire salamanders - spraying of secretions from highly pressurized dorsal skin glands. Herpetologica 46: 1-7.

Buckley D, Alcobendas M, García-París M, Wake MH. 2007. Heterochrony, cannibalism, and the evolution of viviparity in Salamandra salamandra. Evolution and Development 9: 105115 .

Bulog B, Bizjak Mali L, Kos M, Mihajl K, Prelovšek P-M, Aljančič G. 2000. Biology and functional morphology of Proteus anguinus (Amphibia, Caudata). Acta Biologica Slovenika 43: 85-102.

Chauvin M von. 1883. Die Art der Fortpflanzung des Proteus anguineus. Zeitschrift für wissenschaftliche Zoologie 38: 671685.

Coen DR. 2006. Living precisely in fin-de-siècle Vienna. Journal of the History of Biology 39: 493-523.

Configliachi P, Rusconi M. 1819. Del proteo anguino di Laurenti: monografia. Pavia.

Dopazo H, Alberch P. 1994. Preliminary results on optional viviparity and intrauterine siblicide in Salamandra salamandra populations from northern Spain. Mertensiella 4: 125-138. 
Durand JP. 1976. Ocular development and involution in the European cave salamander, Proteus anguinus Laurenti. Biological Bulletin 151: 450-466.

Fox HM. 1923. Dr. Kammerer's Ciona experiments. Nature 112: 653-654.

Fox HM. 1924. Note on Kammerer's experiments with Ciona concerning the inheritance of an acquired character. Journal of Genetics 14: 89-91.

García-París M, Alcobendas M, Buckley D, Wake DB. 2003. Dispersal across contact zones in Iberian populations of fire salamanders (Salamanda salamandra) inferred from discordance of genetic and morphological traits. Evolution 57: 129-143.

Gliboff S. 2005. 'Protoplasm is soft wax in our hands': Paul Kammerer and the art of biological transformation. Endeavour 29: 162-167.

Gliboff S. 2006. The case of Paul Kammerer: evolution and experimentation in the early 20th century. Journal of the History of Biology 39: 525-536.

Gliboff S. 2010. Did Paul Kammerer discover epigenetic inheritance? No and why not. Journal of Experimental Zoology, Molecular and Developmental Evolution 314B: 616-624.

Greven H. 2003. Larviparity and pueriparity. Pp. 447-475 in DM Sever (ed.) Reproductive Biology and Phylogeny. Volume 1, Reproductive Biology and Phylogeny of Urodela. Science Publisher Inc., Enfield.

Herbst C. 1924. Beiträge zur Entwicklungsphysiologie der Färbung und Zeichnung der Tiere. 2. Die Weiterzucht der Tiere in gelber und schwarzer Umgebung. Archiv Mikroskopische Anatomie 102: 130-167.

Hirschmüller A. 1991. Paul Kammerer und die Vererbung erworbener Eigenschaften. Medizinhistorisches Journal. Internationale Vierteljahresheft für Wissenschaftsgeschichte 26: 2677.

Honigmann H. 1908. Die Fortpflanzung des Grottenolms. Lacerta, Beilage zur Wochenschrift Aquarien- und Terrarienkunde 9: 36.

Ivanović A., Aljančič G., Arntzen JW. 2013. Skull shape differentiation of black and white olms (Proteus anguinus anguinus and Proteus a. parkelj): an exploratory analysis with micro CT scanning. Contributions to Zoology 82: 107-114.

Joseph H. 1933. Tatsächliches zur Frage des Olmauges. Biologia Generalis 9: 151-167. Wien, Leipzig: Versluys Festschrift, Emil Haim \& Co.

Juberthie C, Durand JP, Dupuy M. 1996. La reproduction des Protées (Proteus anguinus): bilan de 35 ans d'élevage dans les grottes-laboratoires de Moulis et d'Aulignac. Mémoires de Biospéologie 23: 53-56.

Kammerer P. 1904. Beitrag zur Erkenntnis der Verwandtschaftsverhältnisse von Salamandra atra und maculosa. Archiv für Entwicklungsmechanik der Organismen 17: 165-264.

Kammerer P. 1905. Mein Pfingstausflug 1905. Blätter für Aquarien- und Terrarienkunde 16: 288-290, 297-299, 303-304.

Kammerer P. 1907a. Die Fortpflanzung des Grottenolmes (Proteus anguinus Laurenti). Verhandlungen der Zoologischbotanischen Gesellschaft in Wien 57: 277-292.

Kammerer P. 1907b. Vererbung erzwungener Fortpflanzungsanpassungen. 1. und II. Mitteilung: Die Nachkommen der spatgeborenen Salamandra maculosa und der fruhgeborenen $\mathrm{Sa}$ lamandra atra. Archiv für Entwicklungsmechanik der Organismen 25: 7-51.
Kammerer P. 1911. Direkt induzierte Farbanpassungen und deren Vererbung. Vortrag, gehalten dem VIII. Internationalen Zoologenkongresse zu Graz. Zeitschrift Induktive Abstammungsund Vererbungslehre 4: 279-288.

Kammerer P. 1912. Experimente über Fortpflanzung, Farbe, Augen und Körperreduction bei Proteus anguinus Laur. (zugleich: Vererbung erzwungener Farbveränderungen, III. Mitteilung). Archiv für Entwicklungsmechanik der Organismen 33: 349-461.

Kammerer P. 1913. Vererbung erzwungener Farbveränderungen, IV. Mitteilung: Das Farbkleid des Feuersalamanders (Salamandra maculosa Laurenti) in seiner Abhängigkeit von der Umwelt. Archiv für Entwicklungsmechanik der Organismen 36: 4-193.

Kammerer P. 1914. Aufklärung zu vorstehenden Bemerkungen des Herrn Professor Baur. Archiv für Entwicklungsmechanik der Organismen 38: 684.

Kammerer, P. 1917. Naturforscherreisen zu den Felseneilanden Dalmatiens. Wiener Urania, Vienna: Verlag des Volksbildungshauses.

Kammerer P. 1924. The inheritance of acquired characteristics. New York: Boni and Liveright.

Kammerer P, Wettstein O. 1926. Der Artenwandel auf Inseln und seine Ursachen ermittelt durch Vergleich und Versuch an den Eidechsen der Dalmatischen Eilande. Zur Systematik der Adriatischen Insel-Eidechsen. Vienna, Leipzig: Franz Deuticke.

Kändler R. 1924. Die sexuelle Ausgestaltung de Vorderextremität der anuren Amphibien. Jenaische Zeitschrift für Naturwissenschaft 60, Neue Folge 53: 175-240.

Koestler A. 1971. The case of the Midwife toad. London: Hutchinson.

Liu Y-S. 2011. Inheritance of acquired characters in animals: a historical overview, further evidence and mechanistic explanations. Italian Journal of Zoology 78: 410-417.

Logan CA. 2007. Overheated rats, race, and the double gland: Paul Kammerer, endocrinology and the problem of somatic induction. Journal of the History of Biology 40: 683725.

MacBride EW. 1925. The blindness of cave-animals. Nature 116: 818.

Noble GK. 1926. Kammerer's Alytes. Nature 118: 209-210.

Nusbaum, J. 1907. Ein Fall von Viviparität beim Proteus anguineus. Biologisches Zentralblat 27: 370-374.

Pederzoli A, Gambarelli A, Restani C. 2003. Xanthophore migration from the dermis to the epidermis and dermal remodelling during Salamandra salamandra salamandra (L.) larval development. Pigment Cell Research 16: 50-58.

Pennisi E. 2009. The case of the Midwife toad: fraud or epigenetics? Science 325: 1194-1195.

Schreiber E. 1875. Herpetologia Europaea. Eine systematische Bearbeitung der Amphibien und Reptielen welche bisher in Europa aufgefunden sind. Braunschweig: Friedrich Vieweg und Sohn.

Schreiber E. 1912. Herpetologia Europaea. Eine systematische Bearbeitung der Amphibien und Reptielen welche bisher in Europa aufgefunden sind. Zweite, gänzlich umgearbeitete Auflage. Jena: Gustav Fischer Verlag.

Schulze FE. 1876. Zur Fortpflanzungsgeschichte des Proteus anguineus. Zeitschrift für wissenschaftliche Zoologie 26: 350354. 
Schwalbe G. 1896. Zur Biologie und Entwicklungsgeschichte von Salamandra atra und maculosa. Zeitschrift fur Biologie 34, Neue Folge 16: 340-396.

Senglaub K. 2006. Paul Kammerer (1880-1926), seine Zeit, seine Ziele und seine Züchtungsexperimente mit Feuersalamandern (Salamandra salamandra) und Geburtshelferkröten (Alytes obstetricans). Sekretär 6: 3-26.

Sermonti G. 2000. Eredità epigenetica. In memoria di Paul Kammerer. Epigenetic heredity. In praise of Paul Kammerer. Rivista di Biologia 93: 5-12.

Shaw TR. 1999. Proteus for sale and for science in the $19^{\text {th }}$ century. Acta Carsologica 28: 229-304.

Sket B. Arntzen JW. 1994. A black, non-troglomorphic amphibian from the karst of Slovenia: Proteus anguinus parkelj n. ssp. (Urodela: Proteidae). Contributions to Zoology 64: 33-53.

Svardal H. 2010. Can epigenetics solve the case of the Midwife toad? - a comment on Vargas. Journal of Experimental Zoology, Molecular and Developmental Evolution 314B: 625-628.

Thiesmeier B, Grossenbacher K. 2004. Salamandra salamandra (Linnaeus, 1758) - Feuersalamander. Pp. 1059-1132 in: B Thiesmeier, K Grossenbacher (eds) Handbuch der Reptilien und Amphibien Europas. Schwanzlurche IIB. Aula Verlag, Wiebelsheim.

Valvasor J W. 1689. Die Ehre deß Hertzogthums Crain. Endter: Laybach and Nürnberg.

Vargas AO. 2009. Did Paul Kammerer discover epigenetic inheritance? A modern look at the controversial Midwife toad experiments. Journal of Experimental Zoology, Molecular and Developmental Evolution 312B: 667-678.

Veith M, Steinfartz S, Zardoya R. 1998. A molecular phylogeny of 'true' salamanders (family Salamandridae) and the evolution of terrestriality of reproductive modes. Journal of Zoological Systematics and Evolutionary Research 36: 7-16.

Velo-Antón G, García-París M, Galan P, Cordero-Rivera, A. 2007. The evolution of viviparity in holocene islands: ecological adaptation versus phylogenetic descent along the transition from aquatic to terrestrial environments. Journal of Zoological Systematics and Evolutionary Research 45: 345-352.

Velo-Antón G, Zamudio KR, Cordero-Rivera A. 2012. Genetic drift and rapid evolution of viviparity in insular fire salamanders (Salamandra salamandra). Heredity 108: 410-418.
Velo-Antón G, Santos X, Sanmartın-Villar I, Cordero-Rivera A, Buckley D. 2015. Intraspecific variation in clutch size and maternal investment in pueriparous and larviparous Salamandra salamandra females. Evolutionary Ecology 29: 185-204.

Verrell PA, Brown LE. 1993. Competition among females for mates in a species with male parental care, the Midwife toad Alytes obstetricans. Ethology 93: 247-257.

Voituron Y, Fraipon M de, Issartel J, Guillaume O, Clobert J. 2011. Extreme lifespan of the human fish (Proteus anguinus): a challenge for ageing mechanisms. Biology Letters 7: 105107.

Wake M. 2015. Fetal adaptations for viviparity in amphibians. Journal of Morphology 276: 941-960.

Wagner GP. 2009. Paul Kammerer's Midwife toads: about the reliability of experiments and our ability to make sense of them. Journal of Experimental Zoology, Molecular and Developmental Evolution 312B: 665-666.

Weisman G. 2010. The Midwife toad and Alma Mahler: epigenetics or a matter of deception? The FASEB Journal 24: 25912595.

Weismann A. 1892. Das Keimplasma, eine Theorie der Vererbung. Jena: Fischer.

Whittaker JR. 1975. Siphon regeneration in Ciona. Nature 255: 224-225.

Whittaker JR. 1985. Paul Kammerer and the suspect siphons. MBL Science http://hermes.mbl.edu/publications/pub_archive/ Ciona/Kammerer/index.html

Wisniewski PJ, Wisniewski LM. 1998. Can a salamander change its spots? British Herpetological Society Bulletin 62: 27-28.

Zeller E. 1889. Über die Fortpflanzung des Proteus anguineus und seine Larve. Jahreshefte des Vereins für Vaterländische Naturkunde in Württemberg 291: 131-138.

Zirkle C. 1949. Death of a Science in Russia. Philadelphia: University of Pennsylvania Press.

Zirkle C. 1959. Evolution, Marxian Biology, and the Social Scene. Pennsylvania: University of Pennsylvania Press.

Received: 11 January 2016

Revised and accepted: 8 April 2016

Published online: 15 November 2016

Editor: J. van Rooijen

\section{Online supplementary information}

S1. Stills from the film Salamandra, a production of Mezhrabpom-Film (1928). A - at ca. six minutes into the movie, Professor Karl Zange (Bernhard Götzke) looks up from the magnifying glass and the lizard he is studying. B - at ca. 42 minutes into the movie, Prince Ruprecht Karlstein (N.P. Khmelyov), leader of the patriotic studentunion and conspiracy to Prof. Zange. In the background Berta Begge, laboratory assistant (Elza Temary). 